\title{
Predictors of job satisfaction among nurses working in Ethiopian public hospitals, 2014: institution-based cross-sectional study
}

\author{
Ayele Semachew ${ }^{1 *}$, Tefera Belachew ${ }^{2 \dagger}$, Temamen Tesfaye $^{3 \dagger}$ and Yohannes Mehretie Adinew ${ }^{4+}$
}

\begin{abstract}
Background: Nurses play a pivotal role in determining the efficiency, effectiveness, and sustainability of health care systems. Nurses' job satisfaction plays an important role in the delivery of quality health care. There is paucity of studies addressing job satisfaction among nurses in the public hospital setting in Ethiopia. Thus, this study aimed to assess job satisfaction and factors influencing it among nurses in Jimma zone public hospitals, southwestern Ethiopia.

Methods: An institution-based census was conducted among 316 nurses working in Jimma zone public hospitals from March to April, 2014. A structured self-administered questionnaire based on a modified version of the McCloskey/ Mueller Satisfaction Scale was used. Data were entered using Epi Info version 3.5.3 statistical software and analyzed using SPSS version 20 statistical package. Mean satisfaction scores were compared by independent variables using an independent sample $t$ test and ANOVA. Bivariate and multivariable linear regressions were done.

Results: A total of 316 nurses were included, yielding a response rate of $92.67 \%$. The overall mean job satisfaction was $(67.43 \pm 13.85)$. One third (33.5\%) of the study participants had a low level of job satisfaction. Mutual understandings at work and professional commitment showed significant and positive relationship with overall job satisfaction, while working at an inpatient unit and work load were negatively associated.
\end{abstract}

Conclusions: One third of nurses had a low level of job satisfaction. Professional commitment, workload, working unit, and mutual understanding at work predicted the outcome variable.

Keywords: Job satisfaction, Nursing, Public hospital, Ethiopia, McCloskey/Mueller Satisfaction Scale

Abbreviations: JUSH, Jimma University Specialized Hospital; MDGs, Millennium Development Goals; MMSS, McCloskey/Mueller Satisfaction Scale; OPD, Outpatient department

\section{Background}

Job satisfaction refers to the attitude and feelings people have about their work [1]. Stamps (1997) defined it as "it is the extent to which employees like their jobs [2]". Job satisfaction is one of the most important factors that determine efficiency and productivity of human resources [3].

Health care is a labor-intensive industry [4], and the single-largest health care professional groups within it are nurses [5]. In recent years, a major target of the

\footnotetext{
* Correspondence: ayele.semachew@yahoo.com

${ }^{\dagger}$ Equal contributors

${ }^{1}$ School of Nursing, College of Medicine and Health Sciences, Bahir Dar

University, Bahir Dar, Ethiopia

Full list of author information is available at the end of the article
}

health care delivery system has been the provision of quality care. A fundamental challenge, however, still remains to achieve improved patient outcome [6].

As key members of the health care team, nurses' job satisfaction plays an important role in the delivery of high-quality health care [7]. As the largest health care profession in the world [8], there is no doubt that nurses are key to the achievement of the Millennium Development Goals (MDGs) [9]. They are often the only health professionals accessible to many people in their lifetime, and addressing their satisfaction is a very important issue [10]. In Ethiopia, nurses are the backbone of the health care system [11]. They play a vital role in promoting the health care program of the country by contributing their own share for the achievement of the MDGs [12]. 
Nurses' job satisfaction is a multidimensional phenomenon influenced by many variables [13]. Job dissatisfaction has frequently been cited as the primary reason for a high rate of absenteeism and turnover of nurses which pose a threat to a health care organization's capacity to provide quality care by impeding their efficiency and effectiveness [14]. Nurses' perceptions of the satisfaction with their jobs have positive impacts on customer-perceived service quality in health care services [15].

Nursing staffs in most medical institutions are the most undervalued staff members [16] despite the fact that these are the people who take care of our loved ones around the clock when they are hospitalized [17]. Currently, nurses seem to be less satisfied due to many unidentified factors, and hence, there is a constant threat of attrition [1]. The nursing profession is also unable to attract adequate number of men and women due to salaries, shift schedule, and social perception of nurses [18]; nowadays in Ethiopia, a number of nurses are leaving their profession and are trying to join other nonnursing fields [11]. Therefore, this study set out to assess the level of nurses' job satisfaction and factors associated with it in Jimma zone public hospitals.

\section{Methods}

\section{Study design and setup}

An institution-based census was conducted from March to April, 2014, among 360 nurses with work experience of greater or equal to 6 months working in three public hospitals found in Jimma zone, namely Shenen Gibe, Limu Genet, and Jimma University Specialized Hospital. Jimma is found at $352 \mathrm{~km}$ southwest of Addis Ababa. Based on the 2007 Census, this zone has a total population of 2486155 .

\section{Data collection tool and procedure}

To collect the data, different tools were used in this study.

Part I: Socio-demographic questionnaires developed by the investigators

Part II: McCloskey/Mueller Satisfaction Scale (MMSS) having eight subscales:

(i) Extrinsic reward subscale consisting of three items

(ii) Scheduling subscale consisting of five items

(iii)Family and work balance subscale consisting of two items

(iv)Coworker subscale consisting of two items

(v) Interaction opportunity subscale consisting of four items

(vi) Professional opportunities consisting of four items

(vii)Praise and recognition consisting of four items and
(viii)Control and responsibility consisting of five items and these eight subscales have 29 items

The McCloskey/Mueller Satisfaction Scale (MMSS) was used to assess nurses' job satisfaction [19]. Response options in this study ranged from 1 (very dissatisfied) to 4 (very satisfied) eliminating the neutral response option to encourage participants to make a decision regarding their thoughts and feelings as opposed to indicating that they had no opinion [20]. Questions in this study were developed from a previous study [21] with Cronbach's alpha of 0.95 . In the present study also, the Cronbach's alpha coefficient was 0.90 .

Part III: Nurse-physician communication-related factors having three subscales and items under each subscales were measured with a 5-point Likert scale. In the present study, it showed a Cronbach's alpha value of 0.81 .

(i) Personal factor (measured by three items)

(ii)Organizational factor (measured by six items)

(iii)Mutual understanding at work (measured by three items)

Part IV: Job stress-related factors having four subscales and items under each subscales were measured with a 4-point Likert scale. In the present study, it had a Cronbach's alpha value of 0.81 .

(i) Workload (measured by four items)

(ii)Lack of support (measured by three items)

(iii) Conflict (measured by four items)

(iv) Organizational decision (measured by three items)

Part V: Professional commitment factors having four items measured with a 4-point Likert scale. It has a Cronbach's alpha value of 0.71 .

And lastly, some open-ended questions were used to assess respondents' reasons for being satisfied and dissatisfied.

Five diploma nurses were recruited to distribute, facilitate, and collect the data with close supervision.

\section{Data processing and analysis}

The data were checked for completeness and entered into Epi Info version 3.5.3 statistical software and analyzed using SPSS version 20 statistical package. Descriptive statistics was used to describe the study population in relation to relevant variables.

Each item of the overall job satisfaction were measured by a 4-point Likert scale having a total of 29 items and their sum score ranging from a minimum of 29 to maximum of 116. For cut of value purpose, a datadriven classification system was used to classify the job satisfaction level into low, moderate, and high [22]. 
Mean satisfaction scores were compared by independent variables using an independent sample $t$ test and ANOVA. After checking the assumptions, bivariate and multivariable linear regressions were done to see the association between the independent and the outcome variables. $\beta$ coefficient was used to show independent predictors of satisfaction. Variables with a $p$ value less than 0.05 were considered as statistically significant.

\section{Data quality assurance}

Data quality was controlled by giving trainings and appropriate supervisions for data collectors. The overall supervision was carried out by the principal investigator. The questionnaire was pre-tested using 18 (5\%) nurses that work in Woliso hospital. After analyzing the pretest result, appropriate modifications were made on the MMSS before the actual data collection.

\section{Results}

Socio-demographic characteristics of study participants Out of the expected 341 respondents, 316 agreed to participate in the study, yielding a response rate of 92.7\%. Majority of the participants (85.8\%) work in Jimma University Specialized Hospital (JUSH). The mean age of participants' was $27.87(\mathrm{SD}=6.81)$ years. Almost half $(49.4 \%)$ of the respondents were male. Nearly two thirds (62.3\%) of the respondents were diploma holders. Regarding working units, 20.9 and $20.3 \%$ of them were from the surgical ward and outpatient department (OPD) respectively (Table 1).

\section{Respondents' level of job satisfaction}

Data-driven classification system was used to classify the job satisfaction level into low (value less than 54), moderate (values between 54 and 63), and high (values above 63 of the job satisfaction percentage score). Almost one third (33.5\%) of the study participants had a low level of job satisfaction (Table 2).

The overall mean satisfaction of the study participants was 67.43 ( $\mathrm{SD}=13.85)$, and the highest level of job satisfaction was satisfaction from coworkers with a percentage mean score of 69.8, while satisfaction from professional opportunities had the lowest percentages mean score of 44.9 (Table 3).

More than half (59.8\%) were very dissatisfied with their salary. Regarding compensation for working weekends and holidays, only $4.7 \%$ of respondents were very satisfied. Majority (77.2\%) of the respondents were very satisfied on the relation with nursing peers (Table 4).

Respondents' reasons of satisfaction and dissatisfaction Over two thirds $(68.4 \%)$ of the respondents said their main reason for satisfaction in their work was
Table 1 Socio-demographic characteristics of nurses in Jimma zone public hospitals, southwest Ethiopia, 2014

\begin{tabular}{|c|c|c|c|}
\hline \multicolumn{2}{|c|}{ Socio-demographic characteristics } & \multirow{2}{*}{$\begin{array}{l}\text { Number } \\
271\end{array}$} & \multirow{2}{*}{$\begin{array}{l}\text { Percent } \\
85.8\end{array}$} \\
\hline Working hospital & $\begin{array}{l}\text { Jimma University Specialized } \\
\text { Hospital }\end{array}$ & & \\
\hline & Shenen Gibe Hospital & 20 & 6.3 \\
\hline & Limu Genet Hospital & 25 & 7.9 \\
\hline \multirow[t]{2}{*}{ Sex } & Male & 156 & 49.4 \\
\hline & Female & 160 & 50.6 \\
\hline \multirow[t]{4}{*}{ Marital status } & Married & 137 & 43.4 \\
\hline & Single & 171 & 54.1 \\
\hline & Divorced & 7 & 2.2 \\
\hline & Widowed & 1 & 0.3 \\
\hline \multirow[t]{10}{*}{ Working unit/ward } & Medical ward & 53 & 16.8 \\
\hline & Surgical ward & 66 & 20.9 \\
\hline & ICU & 10 & 3.2 \\
\hline & Major OR & 20 & 6.3 \\
\hline & Pediatrics ward & 42 & 13.3 \\
\hline & Gyn/obs (maternity) & 22 & 7.0 \\
\hline & Ophthalmology unit & 12 & 3.8 \\
\hline & Psychiatry ward & 7 & 2.2 \\
\hline & OPD & 64 & 20.3 \\
\hline & $\begin{array}{l}\text { Chronic illness follow up } \\
\text { clinic }\end{array}$ & 20 & 6.3 \\
\hline \multirow{2}{*}{$\begin{array}{l}\text { Educational } \\
\text { qualification }\end{array}$} & Diploma nurse & 197 & 62.3 \\
\hline & BSc nurse & 119 & 37.7 \\
\hline Total & & 316 & 100 \\
\hline
\end{tabular}

satisfaction in helping clients. Surprisingly, only $8.9 \%$ of them reported professional pleasure as their source of satisfaction, whereas $28.9 \%$ of nurses mentioned workload as a major source of dissatisfaction; $19.6 \%$ stated the performance evaluation process as their major source of dissatisfaction.

\section{Descriptive result for nurse-physician communication, job-related stress, and professional commitment} Nurse-physician communication-related factors have three subscales which include personal factor with mean score of 8.94, organizational factor with mean score of 21.43, and mutual understanding at work with mean score

Table $\mathbf{2}$ Level of job satisfaction among nurses working in Jimma zone public hospitals, southwest Ethiopia, 2014

\begin{tabular}{lll}
\hline Level of job satisfaction & Number & Percent \\
\hline Low & 106 & 33.5 \\
Moderate & 109 & 34.5 \\
High & 101 & 32.0 \\
Total & 316 & 100 \\
\hline
\end{tabular}


Table 3 Percentage mean scores for the summated scales and overall satisfaction $(n=316)$, Jimma zone public hospital, southwest Ethiopia, 2014

\begin{tabular}{lcclcc}
\hline Name of subscale & Mean & SD & $\begin{array}{l}\text { Minimum } \\
(\%)\end{array}$ & $\begin{array}{l}\text { Maximum } \\
(\%)\end{array}$ & $\begin{array}{l}\text { Mean } \\
(\%)\end{array}$ \\
\hline $\begin{array}{l}\text { Satisfaction from } \\
\text { extrinsic reward }\end{array}$ & 6.31 & 2.21 & 25 & 100 & 52.58 \\
$\begin{array}{l}\text { Satisfaction from } \\
\text { scheduling }\end{array}$ & 11.61 & 3.41 & 25 & 100 & 58.04 \\
$\begin{array}{l}\text { Satisfaction from family } \\
\text { and work balance }\end{array}$ & 4.95 & 1.47 & 25 & 100 & 61.87 \\
$\begin{array}{l}\text { Satisfaction from } \\
\text { coworkers }\end{array}$ & 5.58 & 1.49 & 25 & 100 & 69.78 \\
$\begin{array}{l}\text { Satisfaction from } \\
\text { interaction }\end{array}$ & 9.87 & 2.61 & 25 & 100 & 61.69 \\
$\begin{array}{l}\text { Satisfaction from } \\
\text { professional opportunity }\end{array}$ & 7.20 & 2.41 & 25 & 100 & 44.99 \\
$\begin{array}{l}\text { Satisfaction from praise } \\
\text { and recognition }\end{array}$ & 9.74 & 2.74 & 25 & 100 & 60.90 \\
$\begin{array}{l}\text { Satisfaction from control } \\
\text { and responsibility }\end{array}$ & 12.17 & 3.31 & 25 & 100 & 60.94 \\
$\begin{array}{l}\text { Total satisfaction } \\
\text { percentage score }\end{array}$ & 67.43 & 13.85 & 25.00 & 91.38 & 58.13 \\
\hline
\end{tabular}

of 8.91. For job-related stress factors, four subscales were included: workload with a mean score of 8.73 , lack of support with a mean score of 6.73 , conflict with a mean score of 8.25 , organizational decision with a mean score of 6.72 , and, lastly, professional commitment with a mean score of 6.49 (Table 5).

\section{Factors associated with job satisfaction}

Candidate predictor variables from bivariate regression were entered into multiple linear regressions. Even though 13 predictor variables were significant $(p<0.05)$ in the bivariate model, only working unit, mutual understanding at work, professional commitment, and workload were found to be the final predictor of job satisfaction. The overall model was significant $(F=32.42$, $p<0.001)$ and the value of the adjusted $R^{2}$ was 0.37 .

When the variance explained by all other variables in the model is controlled, working unit $(\beta=3.08, p=0.032)$, mutual understanding at work $(\beta=0.78, p<0.001)$, and professional commitment $(\beta=1.62, p<0.001)$ showed significant and positive relationship with overall job satisfaction. However, workload showed a significant but negative relationship with the overall job satisfaction score $(\beta=-2.66, p<0.001)$. The rest of the variables were not significantly associated with job satisfaction (Table 6).

The model explains $37 \%$ of the variance in the outcome variable. A unit increase in professional commitment score would result in the overall job satisfaction score increasing by 1.62 units. A unit increase in the mutual understanding score would result in the overall job satisfaction score increasing by 0.78 units. A unit increase in the workload score would result in the overall job satisfaction score dropping by -2.66 units. And those nurses who were working in the outpatient department (OPD) were 3.08 times more likely to be satisfied than those working in the inpatient unit.

\section{Discussion}

Health professionals especially nurses seem to be less satisfied due to many unidentified factors, and hence, there is a constant threat of attrition. Nowadays in Ethiopia, a number of nurses are leaving their profession to join other non-nursing fields. Therefore, this study set out to assess the level of nurses' job satisfaction and factors associated with it in Jimma zone public hospitals.

The overall job satisfaction mean score of the respondents was found to be $67.43(\mathrm{SD}=13.85)$. And almost one third $(33.5 \%)$ of the study participants had a low level of job satisfaction. This finding is comparable with a study done in Islamabad [23] which showed that $37.14 \%$ of the participants had a low level of job satisfaction. Methodology difference among the studies might have contributed to the result. However, it is lower than the findings of studies conducted in Australia [24], California [25], and India [26] where nurses were highly satisfied. This might be due to difference in socio-economic status and organizational policies including staff handling and infrastructure between the study setups.

Nurses were most satisfied with their coworkers in different studies of Italy [3], Lebanon [27], Jordan [28], and the USA [29] which is consistent with the current study, as the highest level of satisfaction reported was satisfaction from coworkers.

Respondents' least satisfaction was from professional opportunities and extrinsic reward which is in line with studies done in Italy [3] and Kuwait [6] but inconsistent with reports from the USA [29], Lebanon [27], and Jordan [28] that showed nurses with higher satisfaction with regard to career development. This discrepancy might be due to differences in institutional policies of the study setups that lead to substantial difference in opportunities for further education. It is clear that career development, long-term learning, and training activities in nursing promote job satisfaction, increase retention of nurses, and enable continued provision of quality care [30].

Praise and recognition is expected to motivate nurses and make them happy at work [21], but in this study, nurses stated administration from nursing management as a source of dissatisfaction. This is inconsistent with a study done in India [31] where most of the supervisors and matrons were reported to be very cooperative. Majority $(59.8 \%)$ of the respondents were also least satisfied 
Table 4 Percentage distribution of each item in the job satisfaction scale, Jimma zone public hospitals, southwest Ethiopia, 2014

\begin{tabular}{|c|c|c|c|c|c|c|c|c|}
\hline \multirow[t]{2}{*}{ Items } & \multicolumn{2}{|c|}{$\begin{array}{l}\text { Very } \\
\text { dissatisfied }\end{array}$} & \multicolumn{2}{|c|}{$\begin{array}{l}\text { Moderately } \\
\text { dissatisfied }\end{array}$} & \multicolumn{2}{|c|}{$\begin{array}{l}\text { Moderately } \\
\text { Satisfied }\end{array}$} & \multicolumn{2}{|c|}{$\begin{array}{l}\text { Very } \\
\text { satisfied }\end{array}$} \\
\hline & $n$ & $(\%)$ & $n$ & $(\%)$ & $n$ & $(\%)$ & $n$ & $(\%)$ \\
\hline Pay (salary) you receive & 189 & 59.8 & 69 & 21.8 & 46 & 14.6 & 12 & 3.8 \\
\hline Annual leave you receive from the hospital & 69 & 21.8 & 104 & 32.9 & 116 & 36.7 & 27 & 8.5 \\
\hline Sick leave you receive from the hospital & 77 & 24.4 & 83 & 26.3 & 119 & 37.7 & 37 & 11.7 \\
\hline Hours that you work in the hospital & 73 & 23.1 & 63 & 19.9 & 129 & 40.8 & 51 & 16.1 \\
\hline Flexibility in scheduling your working hours & 65 & 20.6 & 82 & 25.9 & 134 & 42.4 & 35 & 11.1 \\
\hline Your satisfaction in your shift rotation & 51 & 16.1 & 72 & 22.8 & 143 & 45.3 & 50 & 15.8 \\
\hline Flexibility in scheduling your weekends off & 117 & 37.0 & 84 & 26.6 & 88 & 27.8 & 27 & 8.5 \\
\hline Compensation for working weekends and holidays & 126 & 39.9 & 85 & 26.9 & 90 & 28.5 & 15 & 4.7 \\
\hline Opportunity for part-time work & 116 & 36.7 & 92 & 29.1 & 79 & 25.0 & 29 & 9.2 \\
\hline Maternity leave time given by the hospital & 34 & 10.8 & 52 & 16.5 & 147 & 46.5 & 83 & 26.3 \\
\hline Interaction with your nursing peers & 21 & 6.6 & 51 & 16.1 & 152 & 48.1 & 92 & 29.1 \\
\hline Interaction with the physicians you work with & 47 & 14.9 & 86 & 27.2 & 134 & 42.4 & 49 & 15.5 \\
\hline $\begin{array}{l}\text { Availability of medical equipment/supplies to deliver nursing } \\
\text { care in your unit }\end{array}$ & 113 & 35.8 & 100 & 31.6 & 81 & 25.6 & 22 & 7.0 \\
\hline Satisfaction with the nursing care given to your clients & 28 & 8.9 & 60 & 19.0 & 148 & 46.8 & 80 & 25.3 \\
\hline Opportunities for social contact with your colleagues after work & 49 & 15.5 & 80 & 25.3 & 151 & 47.8 & 36 & 11.4 \\
\hline Opportunities for interact professionally with other disciplines & 60 & 19.0 & 101 & 32.0 & 125 & 39.6 & 30 & 9.5 \\
\hline $\begin{array}{l}\text { Opportunities for further education/degree or postgraduate } \\
\text { study in nursing }\end{array}$ & 134 & 42.4 & 75 & 23.7 & 73 & 23.1 & 34 & 10.8 \\
\hline Opportunities to participate in morning rounds & 73 & 23.1 & 86 & 27.2 & 112 & 35.4 & 45 & 14.2 \\
\hline Opportunities to participate in nursing research & 210 & 66.5 & 70 & 22.2 & 28 & 8.9 & 8 & 2.5 \\
\hline Opportunities to write and publish & 255 & 80.7 & 36 & 11.4 & 18 & 5.7 & 7 & 2.2 \\
\hline Recognition from your head nurse & 46 & 14.6 & 84 & 26.6 & 135 & 42.7 & 51 & 16.1 \\
\hline Recognition for your work from superiors & 95 & 30.1 & 98 & 31.0 & 98 & 31.0 & 25 & 7.9 \\
\hline Recognition for your work from peers & 35 & 11.1 & 64 & 20.3 & 152 & 48.1 & 65 & 20.6 \\
\hline Encouragement and positive feedback from matron & 100 & 31.6 & 93 & 29.4 & 86 & 27.2 & 37 & 11.7 \\
\hline Opportunity to make autonomous nursing care decisions & 62 & 19.6 & 85 & 26.9 & 128 & 40.5 & 41 & 13.0 \\
\hline Opportunities for on-the-job training & 184 & 58.2 & 62 & 19.6 & 52 & 16.5 & 18 & 5.7 \\
\hline Responsibility in the unit/ward & 40 & 12.7 & 69 & 21.8 & 134 & 42.4 & 72 & 23.1 \\
\hline Your control over conditions in your working unit & 39 & 12.3 & 62 & 19.6 & 151 & 47.8 & 64 & 20.3 \\
\hline $\begin{array}{l}\text { Consideration given to your opinion and suggestions for change in the } \\
\text { work setting or office practice }\end{array}$ & 58 & 18.4 & 88 & 27.8 & 128 & 40.5 & 42 & 13.3 \\
\hline
\end{tabular}

with their salary which is consistent with studies from Turkey [32] and Australia [23] in which around 60\% of nurses were least satisfied with their pay.

Nurses in hospitals today provide care for an increasing number of patients with chronic conditions [33], and these cases are managed at the inpatient unit. This can increase the work burden of nurses working in the inpatient unit and make them less satisfied. The finding of the present study also revealed that nurses working at the inpatient unit were less satisfied. This is consistent with a study done in Jordan [28] where nurses working in inpatient units deal with more severely ill patients and were less satisfied. Workload also predicted job satisfaction negatively. Many respondents also mentioned workload as a reason to be less satisfied, which is consistent with studies done in the USA [34] and Taiwan [35] that reported workloads' significant negative relation to job satisfaction.

Professional commitment was found to have an effect on nurses' job satisfaction; which is in line with studies done in China [36-38] that revealed professional commitment as a strong predictor for job satisfaction. Individuals with high levels of professional commitment are more likely to engage in activities that favor their organization [39].

In this study, mutual understanding predicts a nurse's job satisfaction positively. This is consistent with studies 
Table 5 Descriptive result for nurse-physician communicationrelated factors, job-related stress factors, and professional commitment in Jimma zone public hospitals, southwest Ethiopia, 2014

\begin{tabular}{lccrc}
\hline & Minimum & Maximum & Mean & Std. deviation \\
\hline Personal factor & 3.00 & 15.00 & 8.94 & 3.47 \\
Organizational factor & 6.00 & 30.00 & 21.43 & 5.70 \\
Mutual understanding & 3.00 & 15.00 & 8.91 & 2.87 \\
at work & & & & \\
Workload total score & 4.00 & 16.00 & 8.73 & 2.34 \\
Lack of support & 3.00 & 12.00 & 6.73 & 2.24 \\
Conflict total & 4.00 & 16.00 & 8.25 & 2.69 \\
Organizational decision & 3.00 & 12.00 & 6.72 & 1.94 \\
Professional commitment & 4.00 & 16.00 & 9.46 & 2.59 \\
\hline
\end{tabular}

done in Iran [40] and the West Coast region [41] where nurse-physician relationships had impact on nurses' satisfaction. When there is mutual understanding at work, there is a sense of recognition and feeling of respect between them, which further brings satisfaction at work.

Diploma nurses were more satisfied than degree nurses. This finding is in line with studies done in the USA [42] and Kuwait [6] that proved nurses with higher levels of education were less satisfied with their occupation. A probable reason could be that more educated employees have higher levels of expectations which health care institutions are often unable to fulfill.

More than two thirds (69\%) of nurses stated helping clients as a source of satisfaction at work; this result is

Table 6 Multivariable linear regression predicting job satisfaction among nurses working in Jimma zone public hospitals, southwest Ethiopia, 2014

\begin{tabular}{|c|c|c|c|c|c|c|}
\hline \multicolumn{7}{|l|}{ Coefficients $^{a}$} \\
\hline & \multicolumn{2}{|c|}{$\begin{array}{l}\text { Unstandardized } \\
\text { coefficients }\end{array}$} & \multirow[t]{2}{*}{$t$} & \multirow[t]{2}{*}{$p$} & \multicolumn{2}{|c|}{$95 \% \mathrm{Cl}$ for $\beta$} \\
\hline & $\bar{\beta}$ & $\begin{array}{l}\text { Std. } \\
\text { error }\end{array}$ & & & $\begin{array}{l}\text { Lower } \\
\text { bound }\end{array}$ & $\begin{array}{l}\text { Upper } \\
\text { bound }\end{array}$ \\
\hline (Constant) & 62.171 & 4.70 & 13.23 & 0.000 & 52.92 & 71.42 \\
\hline \multicolumn{7}{|l|}{ Working unit } \\
\hline Outpatient & 3.08 & 1.45 & 2.13 & 0.032 & 0.23 & 5.93 \\
\hline \multicolumn{7}{|l|}{ Inpatient } \\
\hline $\begin{array}{l}\text { Mutual understanding } \\
\text { at work }\end{array}$ & 0.78 & 0.22 & 3.53 & 0.000 & 0.35 & 1.22 \\
\hline $\begin{array}{l}\text { Professional } \\
\text { commitment }\end{array}$ & 1.62 & 0.25 & 6.61 & 0.000 & 1.14 & 2.10 \\
\hline Workload & -2.66 & 0.28 & -9.54 & 0.000 & -3.21 & -2.11 \\
\hline Age (in year) & 0.17 & 0.09 & 1.86 & 0.064 & -0.01 & 0.36 \\
\hline Sex & 0.29 & 1.25 & 0.238 & 0.812 & -2.17 & 2.77 \\
\hline
\end{tabular}

Max VIF $=1.07$, adjusted $R^{2}=0.37$

$\mathrm{Cl}$ confidence interval

${ }^{\mathrm{a}}$ Dependent variable: total satisfaction score in line with a studies done in South Africa (76\%) [43] and Malawi (73\%) [44], where participants reported helping the sick as a source of satisfaction.

\section{Limitations}

The information gained from participants is based upon their subjective perceptions, and it is possible that they either over- or underreported their level of satisfaction. By assuming that nurses can read and understand the English language, there was no need of translating the questionnaire into the local language and this may possibly cause some misunderstanding in some words or terminology.

\section{Conclusions}

One third of the study participants had a low level of job satisfaction. Level of job satisfaction was positively associated with mutual understanding at work and professional commitment, whereas it was found to be negatively associated with working at the inpatient unit and increased workload.

Fostering and maintaining a higher level of job satisfaction among nurses is vital to limit turnover and ensure the delivery of quality care.

\section{Acknowledgements}

We are very grateful to Jimma University for the financial support to this study and to all study participants for their commitment in responding to our questionnaires.

\section{Funding}

Jimma University has covered the per diem for data collectors.

\section{Availability of data and materials}

Not applicable.

\section{Authors' contributions}

AS wrote the proposal, participated in the data collection, analyzed the data, and drafted the paper. TB and TT approved the proposal with some revisions and participated in the data analysis. YM participated in the proposal development and data analysis and drafted the manuscript. All authors read and approved the final manuscript.

\section{Competing interests}

The authors declare that they have no competing interests.

Consent for publication

Written consent was obtained that the interview will be included in publications.

\section{Ethics approval and consent to participate}

Ethical clearance was obtained from Jimma University, College of Public Health and Medical Sciences, institutional review board. A formal letter of cooperation was written to the hospitals.

Participants were informed about the purpose, benefit, risk, the confidentiality of the information, and the voluntary nature of participation.

Data were collected only after informed written consent was obtained.

\section{Publisher's Note}

Springer Nature remains neutral with regard to jurisdictional claims in published maps and institutional affiliations. 


\section{Author details}

${ }^{1}$ School of Nursing, College of Medicine and Health Sciences, Bahir Dar University, Bahir Dar, Ethiopia. 'Department of Population and Family Health, College of Public Health and Medical Sciences, Jimma University, Jimma, Ethiopia. ${ }^{3}$ Department of Nursing, College of Public Health and Medical Sciences, Jimma University, Jimma, Ethiopia. ${ }^{4}$ College of Health Sciences and Medicine, Wolaita Sodo University, Sodo, Ethiopia.

\section{Received: 20 January 2016 Accepted: 12 April 2017}

Published online: 24 April 2017

\section{References}

1. Kumar R, Ahmed J, Shaikh BT, Hafeez R, Hafeez A. Job satisfaction among public health professionals working in public sector: a cross sectional study from Pakistan. Hum Resour Health. 2013:11(2):1-5.

2. Ahmed SM, Tolera M, Angamo MT. Assessment of job satisfaction among pharmacy professionals in south-west Ethiopia. Int J Pharm Sci Res. 2013; 4(6):2351-8

3. Dignani L, Toccaceli A. Nurses and job satisfaction: results of an Italian survey. J US-China Public Adm. 2013;10(4):379-87.

4. Wiki Answers. [Internet]. What is job satisfaction and job dissatisfaction? 2013 [cited 2013 Oct 20]. p. about 2. Available from: http://wiki.answers. com/Q/What_is_job_satisfaction.

5. Kamal A. Canadian nursing labour force: examining the relationship between job dissatisfaction, nurse dissatisfaction and intent to quit. [Internet]. University of Toronto; 2011 [cited 2013 Oct 31]. p. 181. Available from: https://tspace.library.utoronto.ca/handle/1807/30651

6. Al-enezi N, Chowdhury Rl, Shah MA, Al-otabi M. Job satisfaction of nurses with multicultural backgrounds: a questionnaire survey in Kuwait. Appl. Nurs. Res. [Internet]. Elsevier Inc.; 2009 [cited 2013 Oct 29];22(2):94-100. Available from: http://dx.doi.org/10.1016/j.apnr.2007.05.005

7. Olatunji SO, Mokuolu BO. The influence of sex, marital status, and tenure of service on job stress, and job satisfaction of health workers in a Nigerian Federal Health Institution. An Int Multidiscip J [Internet]. 2014;8(1):126-33. Available from: http://www.ajol.info/index.php/afrrev/article/download/101335/90526.

8. Sridharan S, Liyanage U, Wickramasinghe S. Impact of individual factors on job satisfaction of nursing officers in Sri Lankan government hospitals. Sri Lankan J Manag [Internet]. 2008;14(1):48-70. Available from: http://sljm.pim.lk/admin.

9. Spetz. International Centre for Human Resources in Nursing [Internet]. Geneva: International Council of Nurses; 2011. p. 51. Available from: http:// www.nurse.or.jp/nursing/international/icn/report/pdf/2012/02-04-2.pdf.

10. International Council of Nurses. Closing the gap: Millennium Development Goals 8, 7, 6, 5, 4, 3, 2, 1. [Internet]. ... to Conduct. gap assessments Prot. .... Geneva, Switzerland.; 2013 p. 1-58. Available from: ftp://200.130.9.7/ Biblioteca/12962

11. Ethiopian Herald. The Ethiopian Herald. [Internet]. Addis Ababa; 2013 [cited 2013 Oct 12]. p. 2. Available from: http://www.ethpress.gov.et/herald/index. php/herald/national-news/1533-ass-n-to-make-nursing-standardized.

12. Brain Francis. Job Satisfaction, Work Attitudes and Job Motivation. 2013 p. 10. Available from: http://wikispaces.psu.edu/display/PSYCH484/11.+Job +Satisfaction.

13. Breu F, Guggenbichler S, Wollmann J. Nurses' perceived job related stress and job satisfaction in Amman private hospitals. [Internet]. Vasa. 2005 [cited 2013 Oct 31]. p. 31. Available from: http://medcontent.metapress.com/ index/A65RM03P4874243N.pdf

14. Zaghloul A. Intention to stay and nurses' satisfaction dimensions. J Multidiscip Heal [Internet]. 2008;1:51-8. Available from: http://www.ncbi. nlm.nih.gov/pmc/articles/PMC3004551/.

15. Awosusi $\mathrm{O}$, Jegede A. Motivation and job performances among nurses in the Ekiti State Environment of Nigeria. Int J Pharma Bio Sci [Internet]. 2011; 2(2):583-95. Available from: http://ijpbs.net/volume2/issue2/bio/67.pdf.

16. Pillay R. Work satisfaction of professional nurses in South Africa: a comparative analysis of the public and private sectors. Hum Resour Health [Internet]. 2009;7(15):10. Available from: http://www.pubmedcentral.nih.gov/ articlerender.fcgi.

17. Alam M, Mohammad J. Level of job satisfaction and intent to leave among Malaysian nurses. Bus Intell J [Internet]. 2009;3(1):123-37. Available from: http://www.iiuedu.org/images/pdf/BIJ-Vol3No1 January 2010.pdf\#page=125.

18. Al-Ahmadi H. Job satisfaction of nurses in Ministry of Health hospitals in Riyadh, Saudi Arabia. Saudi Med J [Internet]. 2002;966(February):645-50.
Available from: http://www.smj.org.sa/PDFFiles/Jun02/

02JobSatisfactionMS20010.pdf

19. O'Neal A. The effects of work schedule flexibility on job satisfaction of telephone advice nurses. [Internet]. Kennesaw State University; 2012 [cited 2013 Oct 31]. p. 76. Available from: http://digitalcommons.kennesaw.edu/ etd/535/

20. Daniels A. Listening to New Zealand nurses: a survey of intent to leave, job satisfaction, job stress, and burnout. [Internet]. Auckland University of Technology; 2004 [cited 2013 Oct 31]. p. 237. Available from: http://aut. researchgateway.ac.nz/handle/10292/199

21. Bilal Abbas El-Salibi. Job satisfaction among registered nurses working in UAE Ministry of Health hospitals: demographic correlates. UAE Ministry of Health Hospitals; 2012. p. 168.

22. Dagget T, Molla A, Belachew T. Job related stress among nurses working in Jimma Zone public hospitals, South West Ethiopia: a cross sectional study. BMC Nurs. 2016;15:39.

23. Sultana A, Riaz R, Mehmood F, Khurshid R. Level of job satisfaction among nurses working in tertiary care hospitals of Rawalpindi. Rawal Med J [Internet]. 2011;36(2):1-7. Available from: http://www.scopemed. org/?mno=7889.

24. Holland P, Allen B, Cooper B. What nurses want: analysis of the first national survey on nurses' attitudes to work and work conditions in Australia. [Internet]. Melb. Monash Univ. Monash University; 2012 [cited 2013 Oct 31]. p. 52. Available from: http://scholar.google.com/scholar?hl en\&btnG Search\&q intitle

25. Wild P. Nurse practitioner's characteristics and job satisfaction. J Am Acad Nurse Pract [Internet]. 2006;18:544-9. Available from: http://onlinelibrary. wiley.com/doi/10.1111/j.1745-7599.2006.00173.x/full.

26. Saini $S$, Singh C. Job satisfaction among nursing personnel. Nurs Midwifery Res [Internet]. 2005:1(2):64-9. Available from: http://medind.nic.in/nad/t05/ i2/nadt05i2p64.pdf.

27. Fadi El-Jardali, Hani Dimassi, GM, Nuhad Dumit DJ. A national crosssectional study on nurses' intent to leave and job satisfaction in Lebanon: implications for policy and practice. BMC Nurs [Internet]. 2009; 8(3):1-13. Available from: http://www.biomedcentral.com/content/pdf/ 1472-6955-8-3.pdf.

28. Mrayyan M. Jordanian nurses' job satisfaction, patients' satisfaction and quality of nursing care. Int Nurs Rev [Internet]. 2006:53:224-30. Available from: http://onlinelibrary.wiley.com/doi/10.1111/j.1466-7657. 2006.00439.x/full.

29. ANA. Survey of 76,000 nurses probes elements of job satisfaction, USA [Internet]. Med. News Today. 2005 [cited 2013 Nov 3]. p. about 3. Available from: http://www.medicalnewstoday.com/releases/21907.php?fb

30. Davidson H, Folcarelli PH, Crawford S, Duprat $\amalg$, Clifford JC. The effects of health care reforms on job satisfaction and voluntary turnover among hospital-based nurses. Med Care. 1997;35(6):634-45.

31. Rao TK, Malik S. Job satisfaction among nurses: a comparative study of nurses employed in government and private hospitals. J Appl Manag Comput Sci. 2012;1:1-22.

32. Akansel, Neriman, Özkaya G, Illker Ercan ZA. Job satisfactions of nurses and physicians working in the same health care facility in Turkey. Int J Caring Sci [Internet]. 2011;4(3):133-43. Available from: www. inernationaljournalofcaringscienes.org.

33. Debra Thoms. Ways of working in nursing resource package [Internet]. Ways Work. Nurs. 2011. p. 27. Available from: www.health.nsw.gov.au

34. Kalist DE. The determinants of job satisfaction among registered nurses. Am J Heal Sci [Internet]. 2011;2(2):9-18. Available from: http://cluteonline.com/ journals/index.php/AJHS/article/view/6623.

35. Yao Mei Chen, Sue Hui Chen CT, Lo LY. Role stress and job satisfaction for nurse specialists. J Adv Nurs [Internet]. 2007;59(5):497-509. Available from: http://www.ncbi.nlm.nih.gov/pubmed/17681080.

36. Lu KY, Lin PL, Wu CM, Hsieh YL, Chang YY. The relationship among turnover intentions, professional commitment, and job satisfaction of hospital nurses. J Prof Nurs. 2002:18(4):214-9.

37. Lu H, While A, Barriball K. Job satisfaction and its related factors: a questionnaire survey of hospital nurses in Mainland China. Int J Nurs Stud [Internet]. 2007:44:574-88. Available from: http://www.sciencedirect.com/ science/article/pii/S0020748906002239.

38. Li-Se Yang, Yu Fen Chiu, Ya Wen, et al. A study of nurses' job satisfaction: the relationship to professional commitment and friendship networks. Health (Irvine Calif) [Internet]. 2012;4(11):1098-105. Available from: http:// 
www.scirp.org/journal/PaperDownload.aspx?FileName=Health20121100014_ 60353310.pdf\&paperlD=24903.

39. Luca Caricati, rachele La sala GPT mancini. Work climate, work values and professional commitment as predictors of job satisfaction in nurses.

J Nurs. Manag. 2013;11:20-39.

40. Aghamolaei T, Tavafian S. Nurses' perception of nurse-physician communication: a questionnaire-based study in Iran. Int J Hosp Res. 2012; 1(2):77-84.

41. Rosenstein BAH. Nurse-physician relationships: impact on nurse satisfaction and retention. Am J Nurs. 2005;102(6):9.

42. Kalisch BJ, Lee H, Rochman M. Nursing staff teamwork and job satisfaction. J Nurs Manag [Internet]. 2010;18:938-47. Available from: http://onlinelibrary. wiley.com/doi/:10.1111/j.1365-2834.2010.01153.x/full.

43. Atefi, Abdullah, Wong M. Factors influencing job satisfaction among registered nurses: a questionnaire survey in Mashhad, Iran. J Nurs Manag. 2013;23(4):1-11.

44. Jacinta M. Improving nurse retention: factors influencing job satisfaction of all cadres of nurses in Machinga district. University of Malawi College of Medicine; 2008. p. 68.

Submit your next manuscript to BioMed Central and we will help you at every step:

- We accept pre-submission inquiries

- Our selector tool helps you to find the most relevant journal

- We provide round the clock customer support

- Convenient online submission

- Thorough peer review

- Inclusion in PubMed and all major indexing services

- Maximum visibility for your research

Submit your manuscript at www.biomedcentral.com/submit
( ) BioMed Central 